\title{
Foreign Body Stones in the Urinary Bladder of Two Children
}

\author{
İki Çocukta Yabancı Cisim Mesane Taşı
}

\section{Zafer Turkyilmaz ${ }^{1}$, Ramazan Karabulut ${ }^{1}$,Suleyman Yesil ${ }^{2}$, Fazli Polat ${ }^{2}$, Hayrunnisa Oral $^{1}$, Teymurşah Muradi $^{1}$, Kaan Sonmez}

${ }^{1}$ Gazi University, Faculty of Medicine, Department of Pediatric Surgery, Ankara, Turkey

${ }^{2}$ Gazi University, Faculty of Medicine, Department of Urology, Ankara, Turkey

\section{ABSTRACT}

Bladder calculi rarelyseen in children and are usually a manifestation of an underlying pathologic condition of the lower urinary tract, metabolic disease, voiding dysfunction, urinary infection, obstruction, or foreign body retention. However, a forgotten double j stent and a ruptured Foley balloon-induced bladder stone are an unusual complication for children. We report two case of bladder stone induced by a fragment of a ruptured Foley balloon and forgotten double $\mathrm{j}$ stent. The bladder stone and balloon fragment and stent were successfully removed by cystoscopy by using a holmium:yttriumaluminum-garnet (Ho-YAG) laser lithotripter

Key Words: Bladder stone, foreign body, Ho-YAG laser lithotripter

Accepted:09.17.2018

\section{ÖZET}

Mesane taşları çocuklarda nadiren görülür ve genellikle üriner sistem patolojileri, metabolik hastalık, işeme disfonksiyonu, idrar yolu enfeksiyonu, tıkanıklık veya yabancı cisim retansiyonu gibi altta yatan patolojik bir durumunun bir belirtisidir. Bununla birlikte, unutulmuş bir j j stent ve bir Foley balonu parçası tarafından tetiklenen mesane taşı, çocuklar için alışılmadık bir komplikasyondur. Rüptüre Foley balonunun bir parçası ve j j stentinin unutulması tarafından indüklenen iki mesane taşı olgusunu sunuyoruz. Mesane taşı ve balon parçası ve stent holmiyum: holmium:yttriumaluminum-garnet (Ho-YAG) lazer litotriptör kullanılarak sistoskopi ile başarıyla çıkarıldı.

Anahtar Sözcükler: Mesane taşı, yabancı cisim, Ho-YAG lazer litotriptör

Geliş Tarihi: 16.01.2018

Kabul Tarihi:17.09.2018

\section{INTRODUCTION}

Pediatric urolithiasis remains endemic in developing nations, affecting children at ages less than 1 year to adolescence. The prevalence rate is high at $5 \%$ to $15 \%$ compared with $1 \%$ to $5 \%$ in developed countries(1). Over the last few decades, the etiology of urinary calculi in Western countries has shifted from predominantly infectious to metabolic in nature and are mostly found in the kidneys or ureters. Bladder calculi are usually a manifestation of an underlying pathologic condition, including voiding dysfunction, foreign body retention, urinary infection, or obstruction $(2,3)$. The foreign body can be iatrogenic or self-induced. Foreign bodies may enter the bladder from the urethra, bowel, perivesical tissues, or upper urinary tract. Bullets and splinters may enter the bladder by direct penetration(4). The double J (DJ) stent provides drainage for the upper urinary tract, relief of ureteral obstruction and preventing ureteral injuries during surgical procedures. During the last decade significant improvements have been made in stent design and material in order to reduce complications.
However, serious complications such as migration, fragmentation, encrustation, and stone formation still occur, especially when stents are left in place for long periods of time(5).

Herein, we report an unusual cases of huge bladder stone induced by a fragment of a ruptured Foley balloon and forgotten double J stent in two children.

\section{CASE REPORT}

Case 1

A 12-year-old male child consulted with $3 \mathrm{~cm}$ bladder stone due to forgetten doble j stent. He was a known case of urolithiasis and had undergone right-sided ureterorenoscopy/extraction of renal calculi/DJ stent insertion 2 years prior. He had microcephaly, hearing loss and speech impairment. We had previously undergone surgery for atrial and ventricular septal defect. In addition, $1 \mathrm{p}$ microdeletion was diagnosed genetically. Plain X-ray revealed the presence of a DJ ureteral stent on the right side with huge bladder stone (Figure 1). 


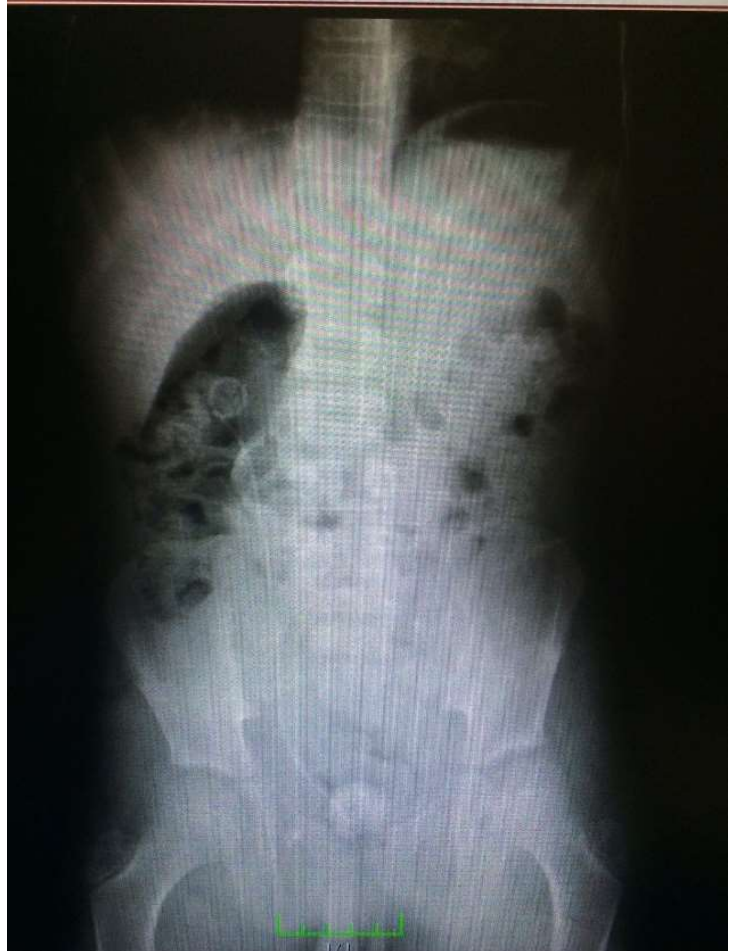

Case 2

A 3-year-old male patient was hematuria a month ago and applied to our clinic for the detection of $2.5 \mathrm{~cm}$ stone in the bladder on ultrasonography. He has received two period antibiotic treatment for urinary tract infection during this time.There was no other pathological conditions. One year ago, he was operated on because of subcoranal hypospadias and during this procedure urethral Foley catheter was used.

Serum biochemical values were normal in both patients. When the urine culture was clean, patients were positioned in lithotomy position under general anesthesia. Urethrocystoscopy was performed for transurethral cystolithotripsy. The stone was fragmented using a holmium:yttriumaluminum-garnet (Ho-YAG) laser lithotripter(Figures 2 and 3).

Figure 1. X-ray: A whole encrusted right double j stent in bladder.
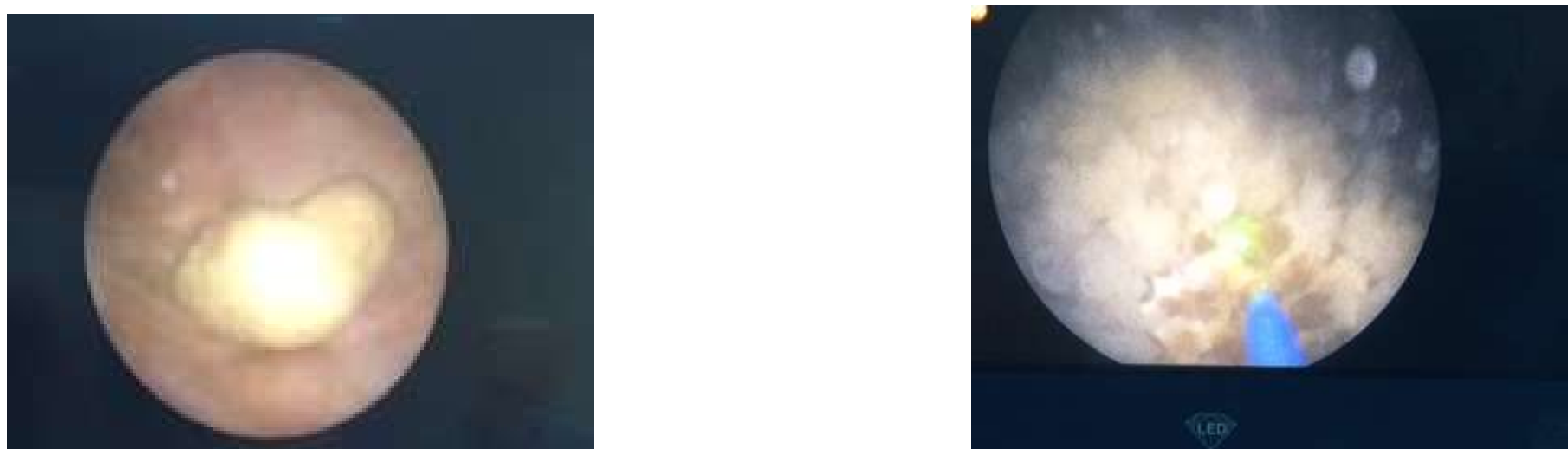

Figures 2, 3: Cystoscopy revealing a giant bladder stone and the stone was fragmented using Ho-YAG laser.

The laser energy and frequency were 0.6-1.0 J and 5-10 Hz, respectively. Stone extraction was not performed routinely, especially fragments smaller than $4 \mathrm{~mm}$ were left to pass spontaneously to reduce operative time. Ruptured fragment of the Foley balloon was found in the middle of the stone.
The DJ stent and the balloon fragment were removed successfully through the cystoscope (Figures 4 and 5). Two patients underwent urinary tract infection requiring antibiotic therapy after the procedure and was discharged the 7 th day.
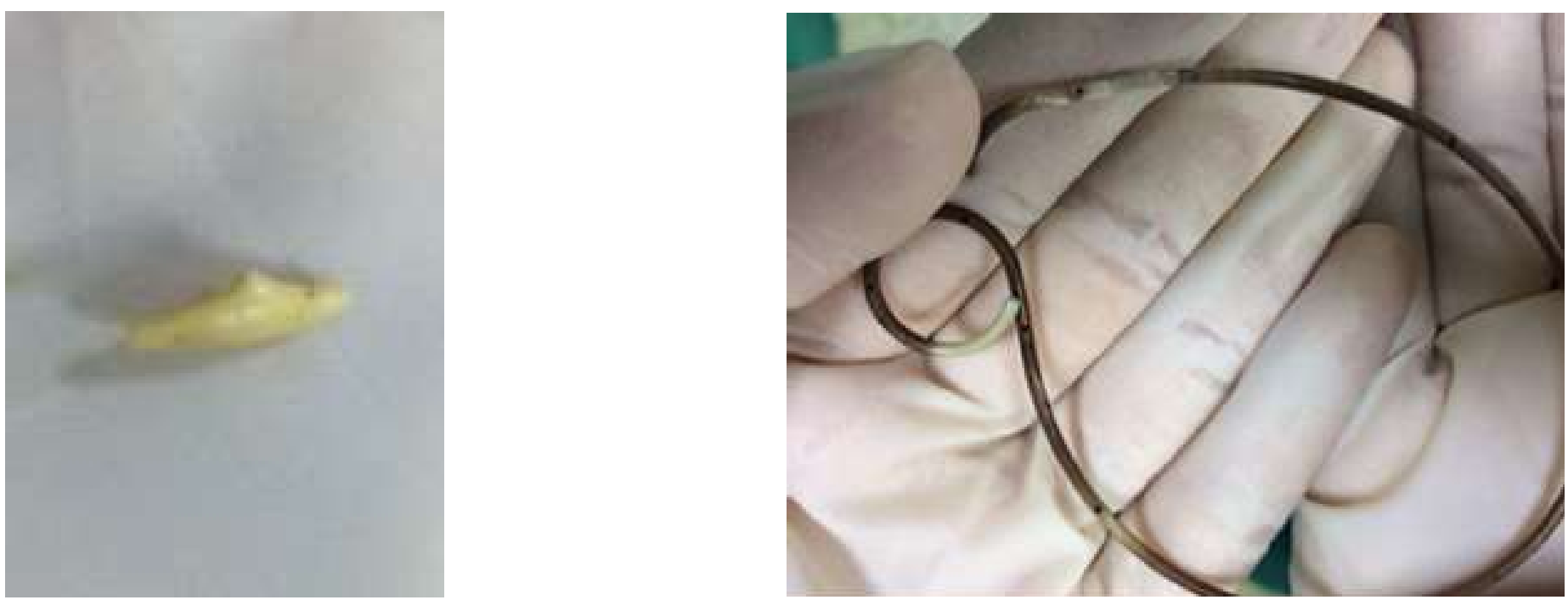

Figures 4, 5: Exracted Foley ballon fragment and DJ stent. 
Bladder calculi account for $5 \%$ of all urinary calculi and usually occur due to indwelling foreign bodies, bladder neck outlet obstruction, urinary tract infection, or stones come from the upper urinary tract. Pediatric bladder calculi are considered endemic when formed in the absence of obstruction, infection or neurogenic disease. They are prevalent in geographic areas where children suffer from malnutrition, diarrheal disease, and/or chronic dehydration. Diet, high environmental temperatures, and diarrhea seem to be the predisposing factors. In geographical areas of the world with a high reported frequency of endemic bladder calculi, commonly referred to as the Afro-Asian stone belt, these factors are common(1,3). In an earlier report from Turkey on the years 1958 to 1960 , bladder stones were seen in $42 \%$ of all pediatric urolithiasis cases(6). Malnutrition, particularly protein deficiency, was the main etiological factor. A subsequent report in 2009 showed bladder stones in only $2 \%$ of cases(7). In addition to the described predispose factors, it is possible to develop bladder stone due to the use of long-lasting urinary catheter, stents and their fragments. It is well known that patients with longterm Foley catheter placement are at risk for urinary infection, bladder and urethral erosion, and calculus formation $(3,4,5,8,9)$. Kohler-Ockmore and Feneley reported that $2.2 \%$ of bladder calculi were found in patients with an indwelling Foley catheter for more then 3 months(10). A fragment of the ruptured balloon retained in the urinary bladder acted as a nidus for calculus formation(4,9). DJ ureteral stents have been widely used in urologic practice. DJ ureteral stents have been used for improve drainage in cases of obstruction of urinary passage and they have also been placed after iatrogenic injury and urinary tract reconstructive surgeries. These forgotten or retained ureteral stents could lead to various complications such as stent occlusion and migration, breakage, encrustation, and stone formation. Despite improved design and biomaterial used, encrustation remains one of the most important side effects. Encrustations are most frequently noted in forgotten/retained DJ stents, which remain indwelling for a long period of time $(1,5)$. Nerli et al. investigted 14 children who underwent removal of forgotten/retained DJ ureteral stents. They said that forgotten/ retained stents are cause morbidity, hospitalization, and definitely a financial strain. In this case, the child developed huge and multiple stones on both ends of the retained DJ stent, needing to undergo prolonged surgery(1). El-Faqih et al. reported encrustation rate of $9.2 \%$ if the DJ was kept for < 6 weeks; however, encrustation rate rose to $76.3 \%$ if the DJ was left in place for up to 12 weeks(11).The clinical manifestations that lead patients to consult are variable and nonspecific. They include urinary frequency, urge incontinence, voiding burns and variable intensity cystalgia when the foreign body engages in the bladder neck it causes dysuria or acute retention of urine(9). The abdominal radiograph may show calcifications projecting on the vesical area and also the foreign body if it is radio-opaque because it is often masked by a calcic stone. The ultrasonography showed hyperechoic images with posterior cone of shadow. While computed tomography urography is rarely requested, except when a repercussion on the upper urinary tract is suspected $(3,8,9)$.

Foreign body stones of the urinary bladder are mostly composed of a mixture of struvite and carbonate apatite, which are components of stones due to infection. Alteration of urine $\mathrm{pH}$ due to infection by urea-splitting bacteria, typically Proteus mirabilis, is an established causative factor in the development of these stones(4).

Bladder stone can be easily removed with open surgery but minimally invasive endourologic management for bladder stone with double J stent and other foreign bodies is well established. In case of severe incrustations, management modalities are more complex. Many investigators have employed ESWL, URS-SE, laser-lithotripsy, PCNL, chemolysis using various chemolytic agents administered via a percutaneous nephrostomy tube, and open surgery either alone or in combination with other procedures $(1,4,5,9,12)$.

Every catheter inserted in the genitouriner system should be used for a short time and the dates of removal of these medical equipment should be well described.

\section{Conflict of interest}

No conflict of interest was declared by the authors.
1. Nerli RB, Patil SM, Magdum P, Sharma V, Ghagane S, Hiremath MB Dixit N. Retained Double J Stent with Huge Renal and Bladder Calculi Extracted by Percutaneous Nephrolithotomy and Percutaneous Cystolitholapaxy in a Single Encounter. J Endourol Case Rep 2017;3:67-9.

2. Khosa AS, Hussain M, Hussain M. Safety and efficacy of transurethral pneumatic lithotripsy for bladder calculi in children. J Pak Med Assoc 2012;62:1297-300.

3. Soliman NA, Rizvi SA. Endemic bladder calculi in children. Pediatr Nephrol 2017;32(9):1489-99.

4. Juan YS, Chen CK, Jang MY, Shen JT, Wang CJ, Chou YH, Huang CH Foreign body stone in the urinary bladder: a case report. Kaohsiung J Med Sci 2004;20:90-2.

5. Kelkar V, Patil D. Management of forgotten double J stent and severe multiple large encrusted stones in the bladder and renal pelvis. Cent European J Urol 2012;65:238-41.

6. Eckstein HB. Endemic urinary lithiasis in Turkish children: a clinical study of 119 cases. Arch Dis Child 1961; 36:137-45.

7. Alpay H, Ozen A, Gokce I, Biykli N. Clinical and metabolic features of urolithiasis and microlithiasis in children. Pediatr Nephrol 2009; 24: 2203-9.

8. Wu FM, Lim M, Deng $Z$, Heng $C T$, Tiong HY. Successful endourological management of the 'forgotten' stent in a transplanted kidney. Urol Int 2014;92:373-6.

9. Aziz el M, Amrani M, Abdelhak K, Hassan FM. A fragment of Foley catheter balloon as a cause of bladder stone in woman. Pan Afr Med J 2015;21:284.

10. Kohler-Ockmore J, Feneley RC. Long-term catheterization of the bladder: prevalence and morbidity. Br J Urol 1996;77:347-51.

11. El-Faqih SR, Shamsuddin AB, Chakrabarti A, et al. Polyurethane internal ureteral stents in treatment of stone patients: Morbidity related to indwelling times. J Urol 1991;146:1817-20.

12. Gangkak G, Yadav SS, Tomar V, Vyas N, Jain D. Pneumatic cystolithotripsy versus holmium:yag laser cystolithotripsy in the treatment of pediatric bladder stones: a prospective randomized study. Pediatr Surg Int 2016;32:609-14. 